\title{
Hubungan Penerapan Total Quality Service (TQS) terhadap Kepuasan Pasien Dalam Pelayanan BPJ S Kesehatan
}

\author{
Haslizar Zein ${ }^{1}$, Mustofa² \\ 1Puskesmas Kecamatan J agakarsa, J.. Batu No. 1, Serengseng Sawah, Jakarta Selatan. \\ ${ }^{2}$ Program Sarjana Kesehatan Masyarakat, Sekolah Tinggi IImu Kesehatan Indonesia Maju \\ J. Harapan Nomor 50, Lenteng Agung - Jakarta Selatan 12610, Telp: (021) 78894045 \\ Email: 'haslizarzein@gmail.com. mstp97@yahoo.co.id
}

\begin{abstract}
Abstrak
Pelayanan kesehatan pada masyarakat yang bermutu masih menjadi persoalan yang perlu mendapatkan perhatian dari semua pihak yang terkait. Tuntutan masyarakat semakin meningkat terhadap mutu pelayanan kesehatan, salah satu keluhan yang sering terdengar dari masyarakat yang berhubungan dengan pelayanan puskesmas. Tujuan penelitian ini adalah untuk mengetahui hubungan penerapan Total Quality Service (TQS) terhadap kepuasan pasien dalam pelayanan BPJS Kesehatan di Puskesmas Kecamatan Jagakarsa Tahun 20I5. Penelitian ini menggunakan metode deskriptif analitik. Penelitian dilakukan di Puskesmas Kecamatan Jagakarsa Jakarta Selatan. Populasi sasaran adalah pasien BPJS sebanyak I 32 orang. Sampel dalam penelitian berjumlah 100 pasien. Teknik pengambilan sampel menggunakan purposive sampling. Hasil penelitian menunjukkan karakteristik pasien yang dirawat di Puskesmas Kecamatan Jagakarsa adalah sebagian besar berusia antara 26 tahun hingga 35 tahun yaitu sebanyak $56 \%$. Pendidikan responden lebih banyak D3 yaitu $45 \%$. Pekerjaan responden sebagian besar sebagai PNS yaitu $45 \%$. Infrastruktur, kualitas SDM dan pelayanan administrasi di Puskesmas Kecamatan Jagakarsa termasuk dalam kategori baik dan sesuai dengan rata-rata nilai frekuensi diatas 70\%. Infrastruktur (Pvalue=0.002), kualitas dan SDM (Pvalue=0.003) memiliki hubungan yang signifikan dengan kepuasan pasien dalam pelayanan BPJS di Puskesmas Kecamatan Jagakarsa.Saran penelitian diharapkan petugas keamanan menunjukan sikap ramah, sopan dan sabar terhadap pasien dan keluarganya. Diperlukan perbaikan kulaitas SDM dari segi keramahan, kesigapan, kesabaran dalam menerima pasien (perawat), komunikasi yang belum optimal dengan pasien (perawat tidak memperkenalkan diri kepada pasien), kesediaan waktu dokter untuk menjelaskan mengenai diagnosis dan hasil pengobatan dan ketepatan waktu kunjungan.
\end{abstract}

Kata kunci : Infrastuktur, Kepuasan Pasien, Total Quality Service

\begin{abstract}
Health services in the community that quality is still an issue that needs the attention of all parties concerned. Increasing public demands for the quality of health care, one that is often heard complaints from the public relating to health center services. The purpose of this study was to determine the relationship of the application of Total Quality Service (TQS) to the satisfaction of patients in health care at the health center BPJS Jagakarsa year 2015. This study used a descriptive analytical method. The study was conducted at the Puskesmas Jagakarsa. Samples of 100 patients. The sampling technique used purposive sampling. Results showed the characteristics of patients treated at health centers Jagakarsa are mostly aged between 26 years to 35 years is as much as $56 \%$. More education respondents D3 is $45 \%$. Most of the respondents work as civil servants is $45 \%$. Infrastructure and quality of human resources at the health center Jagakarsa included in both categories and according to the average frequency values above $70 \%$. Infrastructure (Pvalue $=0.002$ ) and quality of human resources (Pvalue $=0.003$ ) have a significant relationship with patient satisfaction in service in Puskesmas Subdistrict BPJS Jagakarsa. Suggestions are security officers are expected to show a friendly attitude, polite and patient with the patient and his family. HR Quality needed improvements in terms of friendliness, attentiveness, patience in receiving patients (nurses), which is not optimal communication with patients (nurses did not introduce himself to the patient), the willingness of a doctor to explain the diagnosis and treatment outcome and timeliness of the visit.
\end{abstract}

Keywords : Infrastructure, Patient Satisfaction, Total Quality Service 


\section{Pendahuluan}

Puskesmas merupakan salah satu bentuk sarana pelayanan kesehatan yang dapat diselenggarakan oleh pemerintah dan swasta. Pelayanan kesehatan diPuskesmas terdiri atas kegiatan pelayanan rawat jalan, pelayanan rawat inap, dan pelayanan gawat darurat yang mencakup pelayanan medis dan penunjang medis. ${ }^{1}$

Pelayanan jasa dibidang kesehatan merupakan salah satu bentuk pelayanan yang paling banyak dibutuhkan oleh masyarakat. Salah satu sarana pelayanan kesehatan yang mempunyai peranan sangat penting dalam memberikan pelayanan kesehatan kepada masyarakat adalah Puskesmas. Puskesmas merupakan suatu lembaga kesehatan untuk mengemban tugas memberikan pelayanan kesehatan kepada seluruh masyarakat sebagai pembangunan nasional dibidang kesehatan. Pelayanan dibidang kesehatan perlu untuk selalu dibenahi agar bisa memberikan pelayanan kesehatan yang terbaik untuk masyarakat. Pelayanan kesehatan yang dimaksud tentunya adalah pelayanan yang cepat, tepat, murah dan ramah. Mengingat keberadaan Puskesmas pemerintah dan swasta serta munculnya klinik-klinik kesehatan menyebabkan terjadinya persaingan yang ketat dalam menyediakan jasa pelayanan kesehatan. ${ }^{2}$

Persaingan lembaga kesehatan baik Pemerintah, Swasta dan Asing akan semakin keras untuk merebut pasar yang semakin terbuka bebas. Selain hal tersebut, masyarakat menuntut Puskesmas harus dapat memberikan pelayanan dengan konsep quality one step services, artinya seluruh kebutuhan pelayanan kesehatan dan pelayanan yang terkait pasien langsung harus dapat dilayani oleh Puskesmas secara cepat, akurat, bermutu dengan biaya terjangkau. ${ }^{3}$

Pelayanan kesehatan pada masyarakat yang bermutu masih menjadi persoalan yang perlu mendapatkan perhatian dari semua pihak yang terkait. Tuntutan masyarakat semakin meningkat terhadap mutu pelayanan kesehatan, salah satu keluhan yang sering terdengar dari masyarakat yang berhubungan dengan aparatur pemerintah adalah selain berbelit-belit akibat birokrasi yang kaku, perilaku oknum aparatur yang kadang kala kurang bersahabat, juga kepuasan pasien dalam memberikan pelayanan dalam hal ini ketepatan waktu dalam memberikan pelayanan, kuantitas dan mutu pelayanan yang masih sangat rendah. ${ }^{4}$

Kondisi ruang menuntut petugas memiliki kemampuan untuk melakukan penilaian efektif pada kondisi pasien, hal ini pada gilirannya mempengaruhi mutu pelayanan di ruang, seperti rencana tindakan kebutuhan pasien, evaluasi kesehatan pasien sampai pencatatan riwayat kesehatan pasien. Pencatatan riwayat kesehatan pasien yang tidak akurat dapat menyebabkan diagnosis yang tidak akurat, sehingga demikian akan meningkatkan risiko klinis bagi pasien dan menyebabkan ketidakpuasan pasien terhadap pelayanan yang diberikan. ${ }^{5}$

Kepuasan dan konsumen adalah dua hal yang penting bagi kelangsungan suatu industri jasa khususnya pelayanan kesehatan. Kualitas yang baik akan menghasilkan tingkat loyalitas konsumen yang tinggi. Permasalahan kualitas tidak lagi hanya sekedar masalah pengendalian kualitas atas barang atau jasa yang dihasilkan, tetapi pengendalian kualitas lebih berorientasi pada standar jaminan kualitas (quality assurance) yang pada akhirnya akan menuju pencapaian pengelolaan secara total aktivitas pengendalian kualitas. Kondisi ini mengharuskan suatu jasa pelayanan kesehatan untuk selalu berusaha meningkatkan kualitas pelayanan agar kepuasan konsumen dapat terwujud.

Kepuasan pasien akan terpenuhi apabila proses penyampaian jasa pelayanan kesehatan dari Puskesmas kepada konsumen sesuai dengan apa yang dipersepsikan pasien. Pasien yang puas merupakan aset yang sangat berharga karena apabila pasien puas mereka akan terus menerus melakukan pemakaian terhadap jasa pilihanya. Akan tetapi jika pasien merasa tidak puas maka mereka akan memberitahukan kepada orang lain tentang pengalaman buruknya. ${ }^{6}$

Pasien merupakan salah satu pelanggan yang secara langsung merasakan pelayanan di Puskesmas dan perlu mendapatkan pelayanan yang baik agar tercapai harapan dan keinginanya. Pada umumnya pelanggan menginginkan produk yang memiliki karakteristik lebih cepat (faster), lebih murah (Cheaper) dan lebih baik (Better). Mutu pelayanan kesehatan mempengaruhi kepuasan pasien, oleh karena itu untuk menilai mutu pelayanan kesehatan perlu diperhitungkan persepsi pasien Faktor lain yang berhubungan dengan mutu pelayanan adalah adanya kompetisi industri pelayanan kesehatan, Puskesmas harus berjuang untuk meraih konsumen dan pengendali pasar, serta adanya perubahan perubahan yang terjadi dalam lingkup pelayanan kesehatan, sehingga mengakibatkan ketatnya persaingan. Untuk mengatasi semua itu diperlukan pendekatan strategik melalui promosi kesehatan dan keahlian teknis pembuatan keputusan perlu dilakukan untuk mendapatkan solusinya dalam menghadapi problema yang ada.

Tingkat kepuasan pelanggan sangat tergantung pada mutu pelayanan Puskesmas pada umumnya. Pengukuran tingkat kepuasan 
pelanggan erat hubungannya dengan mutu pelayanan. Pengukuran aspek mutu bermanfaat bagi Puskesmas untuk mengetahui proses pelayanan kesehatan berjalan dengan baik atau tidak. $^{8}$

Pelayanan kesehatan yang bermutu merupakan salah satu kebutuhan dasar yang diperlukan setiap orang. Ada 3 pendekatan evaluasi mutu yaitu dari aspek struktur, proses dan outcome. Aspek struktur meliputi sarana fisik, perlengkapan dan peralatan, organisasi dan manajemen, keuangan, sumber daya manusia, dan sumber daya lainnya difasilitas kesehatan. Proses adalah semua kegiatan yang dilaksanakan secara profesional oleh tenaga kesehatan (dokter, perawat dan tenaga profesi lain) dan interaksinya dengan pasien. Sedangkan outcome adalah hasil akhir kegiatan dan tindakan tenaga kesehatan profesional terhadap pasien, dapat berarti adanya perubahan derajat kesehatan dan kepuasan, baik positif maupun negatif. ${ }^{9}$

Hasil poling diketahui bahwa salah satu faktor yang paling sering dikeluhkan oleh pasien adalah lambatnya petugas dalam memberikan pelayanan kesehatan, baik itu pada saat pasien mendaftar diloket sampai dengan pemeriksaan dan pengambilan resep. Hasil pemantauan Pusat Informasi Kesehatan (PIK) diketahui bahwa untuk satu orang pasien diPuskesmas dibutuhkan waktu tunggu dilayani oleh petugas kesehatan 10 menit, diruang periksa 15 sampai 20 menit dan ditempat resep obat mencapai 15 menit, jadi untuk satu kali kunjungan pasien membutuhkan waktu 45 menit sampai 1 jam. ${ }^{10}$

Rendahnya mutu pelayanan akan membangun citra buruk pada Puskesmas, dimana pasien yang merasa tidak puas akan menceritakan kepada rekan-rekannya. Begitu juga sebaliknya, semakin tinggi kepuasan pelayanan yang diberikan akan menjadi nilai plus bagi Puskesmas, dalam hal ini pasien akan merasa puas terhadap pelayanan yang diberikan oleh Puskesmas Kecamatan Jagakarsa. Hasil penelitian dibeberapa Puskesmas didaerah Jawa Barat diketahui bahwa pada umumnya pasien mengeluh dengan antrian pada saat pengurusan administrasi yang mampu mencapai 15 sampai 20 menit. ${ }^{11}$

Hingga saat ini, konsep service quality yang populer dan sering digunakan adalah ServQual oleh Parasuraman, yang menyatakan bahwa kualitas pelayanan memiliki lima dimensi, yaitu reliability, responsiveness, assurance, empathy, dan tangible. Pada penelitian Duggirala, dkk (2008), mereka mencoba membandingkan dimensi pada konsep ServQual dengan dimensi Total Quality Service. Pada konsep Total Quality Service, dimensi keseluruhan pelayanan medis yang diterima dan tanggung jawab sosial merupakan dimensi yang khas, yang tidak terdapat di konsep ServQual. Pertanyanpertanyaan pada konsep Total Quality Service secara kuantitas dan kualitas lebih komprehensif dibandingkan konsep ServQual. Beberapa alasan tersebut yang mendorong peneliti untuk memilih konsep Total Quality Service dalam penelitian ini.

Berdasarkan permasalahan tersebut diatas faktor mutu dan kepuasan dianggap merupakan hal utama yang perlu mendapatkan perhatian manajemen Puskesmas yaitu perlunya meningkatkan keterampilan teknis petugas, keramahan, kemudahan pelayanan, ketersediaan ruangan perawatan, pemeriksaan penunjang dan evaluasi kepuasan pasien.

Evaluasi mutu dan kepuasan pasien terhadap jasa pelayanan yang diterima mengacu pada beberapa faktor, yaitu mutu pelayanan jasa dokter, mutu pelayanan, faktor emosional, biaya serta kelengkapan fasilitas. Sumber daya yang paling banyak mendukung kepuasan pasien di Puskesmas salah satunya adalah tenaga kesahatan perawat dan dokter. Peran tenaga kesehatan memberikan pengaruh besar untuk menentukan mutu pelayanan. Tenaga Kesehatan sebagai ujung tombak pelayanan terhadap pasien dan keluarganya di Puskesmas, karena frekuensi pertemuannya dengan pasien yang paling sering. ${ }^{11}$

Tujuan Penelitian ini adalah Untuk mengetahui hubungan penerapan Total Quality Service (TQS) terhadap kepuasan pasien dalam pelayanan BPJS Kesehatan di Puskesmas Kecamatan Jagakarsa Tahun 2015.

\section{Metode}

Desain penelitian yang digunakan oleh peneliti dalam penelitian ini adalah metode kuantitatif dan deskriptif yaitu suatu penelitian yang mencoba menggali bagaimana dan mengapa fenomena itu terjadi, selanjutnya melakukan analisis dinamika kolerasi antar fenomena tersebut. ${ }^{12}$ Penelitian ini menggunakan rancangan cross sectional adalah suatu penelitian untuk mempelajari dinamika kolerasi antara faktorfaktor resiko atau variabel independen dengan efek atau variabel dependen yang diobservasi atau pengumpulan datanya sekaligus pada suatu saat yang sama. ${ }^{13}$ Variabel independen dalam penelitian ini adalah infrastruktur, kualitas SDM, pelayanan administrasi dan tanggung jawab sosial. yang diukur bersamaan dengan kepuasan pasien dalam pelayaan BPJS Kesehatan (variabel dependen).

Penelitian ini dilakukan di di Puskesmas Kecamatan Jagakarsa ini dipilih karena kualitas pelayanan BPJS Kesehatan dirasakan oleh pasien 
masih rendah tahun 2014 dibandingkan dengan tahun 2013. Penelitian dilakukan pada bulan November 2015. Populasi adalah keseluruhan objek penelitian atau objek yang diteliti yaitu populasi dalam penelitian ini adalah pasien BPJS yang berkunjung ke Puskesmas Kecamatan Jagakarsa periode bulan September 2015. ${ }^{14}$

Sampel adalah bagian dari jumlah dan karakteristik yang dimiliki oleh populasi tersebut. Sampel dalam penelitian ini adalah pasien BPJS Kesehatan yang berkunjung ke Puskesmas Kecamatan Jagakarsa. Pengambilan sampel dengan cara Purposive sampling. ${ }^{15}$

Instrumen penelitian adalah alat-alat yang akan digunakan untuk pengumpulan data. Menurut Arikunto, Instrumen penelitian adalah alat yang digunakan oleh peneliti dalam mengumpulkan data agar pekerjaan lebih mudah dan hasilnya baik sehingga lebih mudah diolah. ${ }^{16}$ Instrumen yang digunakan dalam penelitian ini adalah kuesioner. Kuesioner adalah daftar pertanyaan yang sudah tersusun dengan baik, sudah matang, dimana responden tinggal memberikan jawaban dengan menggunakan tanda-tanda tertentu. Kuesioner yang digunakan dalam penelitian ini menggunakan jenis pertanyaan tertutup. Responden hanya memberi tanda ceklis $(\sqrt{ })$ pada jawaban yang dipilih.

Sebelum melakukan penelitian dikumpulkan data dengan cara menggunakan data sekunder yang didapat dari Puskesmas Kecamatan Jagakarsa tentang jumlah pasien BPJS Kesehatan gambaran puskesmas dan pencarian data-data lain yang relevan dalam mendukung penelitian ini. Langkah pengumpulan data penelitian ini dilakukan dengan cara :(1) Membuat surat permohonan izin pengambilan data dan izin penelitian di Puskesmas Kecamatan Jagakarsa yang dikeluarkan olek BAK STIKIM.(2) Mengajukan izin penelitian kepada kepala Puskesmas Kecamatan Jagakarsa, Kepala Diklat dan Staff TU Puskesmas Kecamatan Jagakarsa untuk mengadakan penelitian. (3) Mengadakan pengkajian data yang relevan yang dapat mendukung penelitian ini. (4) Memberikan penjelasan singkat tentang rencana kegiatan penelitian dan tujuan penelitian kepada pasien BPJS Kesehatan yang bersedia menjadi responden dalam penelitian ini. (5) Responden diberi lembar persetujuan menjadi responden. (6) Responden diberikan kuesioner untuk diisi sesuai dengan petunjuk yang telah diberikan. (7) Mengarahkan respoden untuk mengisi semua item kuesioner yang telah disiapkan dan apabila ada pertanyaan yang kurang dimengerti dapat ditanyakan kepada peneliti. (8) Langkah terakhir setelah kuesioner dikumpulkan dilakukan pengolaha data dan analisa data.

Sebelum kuesioner digunakan untuk mengumpulkan data dari subyek penelitian, terlebih dahulu dilakukan uji coba instrumen dimaksudkan untuk memperoleh alat ukur yang valid dan reliabel. Sebelum diberikan kepada responden, kuesioner terlebih dahulu dilakukan uji coba di puskesmas Kecamatan Pasar Minggu terhadap 20 pasien BPJS Kesehatan yang memiliki karakteristik yang sama dengan responden untuk menguji validitas dan realibitasnya. Instrumen yang valid adalah instrumen yang mampu mengukur apa yang seharusnya diukur. Instrumen yang reliabel adalah instrumen yang bila digunakan beberapa kali akan menghasilkan data yang konsisten sama. ${ }^{17}$

Dalam penelitian ini pengujian validitas instrument menggunakan alat bantu pengolahan SPSS statistic windows versi 18 . Uji validitas adalah suatu indeks yang menunjukkan alat ukur itu benar-benar mengukur apa yang ingin diukur. Untuk mengetahui kuesioner atau pertanyaan yang telah disusun valid atau tidak, maka terlebih dahulu dilakukan uji validitas dengan karakteristik yang sejenis diluar tempat penelitian. Hasil Uji Validitas kuesioner .

Perhitungan hasil validitas dengan menggunakan program SPSS terhadap 33 pertanyaan kuesioner tentang kepuasan pasien. Kuesioner terdiri dari 33 pertanyaan yang memiliki rata-rata angka korelasi diatas angka kritik 0,444 dengan jumlah sampe 20 (n) dan tingkat signifikasi $5 \%$. Apabila terdapat nilai korelasi atribut lebih kecil daripada nilai angka kritik, maka atribut tersebut sebaiknya dihilangkan sehingga nilai keseluruhan akan naik.

Dalam penelitian ini instrument berupa kuesioner yang dibagikan dan diisi langsung oleh responden tentang infrastruktur, kualitas SDM, pelayanan administrasi, tanggung jawab sosial dan kepuasan pasien dalam pelayaan BPJS Kesehatan

Data diolah dengan menggunakan software SPSS for Windows versi 18 yang hasilnya meliputi: (1) Deskripsi Data (Univariat). Deskripsi data univariat ini dilakukan untuk mendapatkan karakteristik setiap variabel yang diteliti. Dalam analisa ini hanya menghasilkan distribusi frekuensi dan persentasi dari setiap variabel. Analisis data yang digunakan adalah univariat terhadap variabel penelitian. Setelah setiap alternatif jawaban diketahui selanjutnya diadakan persentase dengan cara membagi frekuensi setiap jawaban (F) dengan jumlah soal $(\mathrm{N})$ kemudian dikalikan 100.(2) Bivariat (P-Value atau OR atau RR). 
Analisis ini digunakan untuk melihat hubungan terhadap 2 variabel yang diduga berhubungan atau berkolerasi. Pada penelitian ini digunakan variabel bebas (infrastruktur, kualitas SDM, pelayanan administrasi dan tanggung jawab sosial) yang merupakan kelompok yang berpengaruh/berhubungan dengan variabel terikat (terhadap kepuasan pasien dalam pelayaan BPJS Kesehatan). Untuk mengetahui hubungan variabel independen dan dependen dengan uji Chi Square dengan menggunakan program SPSS for window 18.0, untuk mengetahui kebermaknaan nilai $p$ value apakah $\mathrm{H} 0$ diterima atau ditolak.

Hasil akhir uji statistik adalah mengetahui apakah keputusan uji H0 ditolak/gagal ditolak. Ketentuan jika $\mathrm{p}$ value $<\alpha(0,05)$ maka $\mathrm{H} 0$ ditolak. Artinya ada hubungan yang bermakna antara variabel independen dan dependen.

Dalam bidang kesehatan untuk mengetahui derajat hubungan, dikenal ukuran resiko relative (RR) dan odss ratio (OR). Risiko relative membandingkan risiko pada kelompok terekspose dengan kelompok tidak terkespose. Sedangkan osdd rasio membandingkan odd pada kelompok ter-ekspose. Ukuran RR pada umumnya digunakan pada desain Kohort, sedangkan ukuran OR biasanya digunakan pada desain kasus control atau potong lintang (Cros sectional), dan dalam penelitian ini peneliti menggunakan nilai OR.

Data disajikan dengan cara narasi, dan data yang ditampilkan yaitu data yang menonjol. Apabila narasi melengkapi sebuah tabel, hanya ditekankan pada data yang menjadi point interest, tidak semua data yang akan diuraikan. Penyajian data secara tabular yaitu memberikan keterangan berbentuk angka. Jenis yang digunakan dalam penelitian ini adalah master tabel dan tabel distribusi frekuensi. Dimana data disusun dalam baris dan kolom dengan sedemikian rupa sehingga dapat memberikan gambaran.Selain dapat disajikan ke dalam bentuk tabel sebagaimana dikemukakan di atas, data-data angka juga disajikan dalam bentuk grafik, atau lengkapnya grafik frekuensi. Pembuatan grafik frekuensi pada hakikatnya merupakan kelanjutan dari pembuatan tabel distribusi frekuensi karena pembuatan grafik itu haruslah didasarkan pada tabel distribusi frekuensi.

Dengan kata lain, pembuatan tabel distribusi frekuensi harus tetap dilakukan baik kita bermaksud maupun tidak bermaksud membuat grafik frekuensi. Penyajian data angka ke dalam grafik biasanya di pandang lebih menarik karena data-data itu tersaji dalam bentuk visual. Gambar grafik frekuensi yang banyak dipergunakan dalam metode statistik adalah histogram, polygon, kurve dan garis.
Interpretasi disajikan dalam bentuk narasi sehingga memudahkan pemahaman terhadap hasil penelitian. Berdasarkan dari teori yang ada diungkapkan untuk mengetahui hubungan antara infrastruktur, kualitas SDM, pelayanan administrasi dan tanggung jawab sosial terhadap kepuasan pasien dalam pelayaan BPJS Kesehatan di Puskesmas Kecamatan Jagakarsa Tahun 2015.

\section{Hasil}

Penyajian hasil penelitian disusun berdasarkan sistematika yang dimulai dengan gambaran analisis univariat yang bertujuan untuk melihat distribusi frekuensi variabel dependen dan independen. Sedangkan analisis bivariat untuk melihat hubungan antara variabel independen dengan variabel dependen. Variabel independen dalam hal ini adalah variabel Total Quality Service (TQS) yaitu infrastruktur, kualitas SDM, pelayanan administrasi, indikator keselamatan, pengalaman perawatan medis dan tanggung jawab sosial. Sedangkan variabel dependen adalah kepuasan pasien.

Responden pada penelitian ini adalah 100 orang. Berikut ini gambaran karakteristik responden yang meliputi empat aspek yaitu usia, pendidikan, pekerjaan dan pembiayaan kesehatan. Responden yang menjadi subjek pada penelitian ini adalah pasien di Puskesmas Kecamatan Jagakarsa Tahun 2015.

Diketahui mayoritas responden yang berusia antara 26 tahun hingga 35 tahun sebanyak $56 \%$ dan berjenis kelamin laki-laki 56\%. Pendidikan responden lebih banyak Diploma Tiga (D3) yaitu 45\%. Pekerjaan responden lebih banyak berprofesi sebagai PNS yaitu $45 \%$. Responden yang menggunakan biaya ke puskesmas ditanggung BPJS sebanyak 72\%. Hasil penelitian univariat

Tabel 1. Analisis Univariat

\begin{tabular}{lll}
\hline \multicolumn{1}{c}{ Variabel } & $\mathbf{n}$ & $\mathbf{\%}$ \\
\hline $\begin{array}{l}\text { Kepuasan } \\
\text { pasien }\end{array} \quad$ & \\
$\quad$ Puas & & 79 \\
$\quad$ Tidak Puas & 79 & 21 \\
Infrastruktur & 21 & \\
$\quad$ Baik & 72 & 72 \\
$\quad$ Buruk & 28 & 28 \\
Kualitas SDM & & \\
$\quad$ Baik & 71 & 71 \\
$\quad$ Buruk & 29 & 29 \\
Tanggung & & \\
jawap sosial & & \\
$\quad$ Baik & 28 & 28 \\
$\quad$ Buruk & 22 & \\
\hline
\end{tabular}


Berdasarkan data dari tabel 1 diatas, menunjukkan bahwa pasien yang merasa puas selama perawatan di Puskesmas Kecamatan Jagakarsa adalah sebanyak $79 \%$ dan sebanyak 21\% tidak merasa puas.. menunjukkan bahwa menurut pasien infrastruktur di Puskesmas Kecamatan Jagakarsa Tahun 2015 dalam kategori baik yaitu $72 \%$ dan sisanya infrastruktur buruk $28 \%$. Infrastruktur yang buruk menurut responden karena ruangan yang kurang bersih dan kurang nyaman serta ketersediaan ruang tunggu bagi keluarga pasien. menunjukkan bahwa menurut pasien kualitas SDM di Puskesmas Kecamatan Jagakarsa Tahun 2015 dalam kategori baik yaitu 71\% dan sisanya kualitas SDM buruk 29\%.

Kualitas SDM yang buruk menurut responden staff puskesmas (perawat) tidak sepenuhnya membantu pasien dan waktu konsultasi dengan dokter cukup singkat.. menunjukkan bahwa menurut pasien tanggung jawab sosial di Puskesmas Kecamatan Jagakarsa dalam kategori baik yaitu $78 \%$, dan sisanya tanggung jawab sosial buruk 22\%. Tanggung Jawab Sosial yang buruk menurut responden karena pelayanan yang diberikan Puskesmas Kecamatan Jagakarsa tidak adil antara pasien yang satu dengan pasien yang lainnya.

Analisis bivariat adalah Untuk mengidentifikasi variabel Total Quality Service (infrastruktur, kualitas SDM, pelayanan administrasi, indikator keselamatan, pengalaman perawatan medis dan tanggung jawab sosial) mempengaruhi kepuasan pasien sebagai syarat uji lanjutan dalam uji multivariat dapat dilihat sebagai berikut :

Hasil analisis hubungan infrastruktur dengan kepuasan pasien di Puskesmas Kecamatan Jagakarsa Tahun 2015, diketahui dari 79 responden umumnya menyatakan infrastruktur di Puskesmas Kecamatan Jagakarsa Tahun 2015 tergolong baik dan pasien merasakan puas sebanyak 63 responden (88\%) sedangkan infrastruktur buruk dan pasien merasakan puas sebanyak 16 responden (57\%) di Puskesmas Kecamatan Jagakarsa Tahun 2015.

Hasil uji diperoleh nilai OR (Odds Rasio $)=$ 5,25 artinya pasien yang mengaku puas pada infrastruktur yang baik memiliki proporsi lebih tinggi 5,2 kali dibandingkan dengan pasien yang puas dengan infrastruktur buruk. Hasil uji statistik chi square hubungan infrastruktur dengan kepuasan pasien di Puskesmas Kecamatan Jagakarsa Tahun 2015 diperoleh nilai $\mathrm{p}=$ 0,002 artinya $p$. value $\leq$ alpha $(0,05)$, sehingga dapat disimpulkan hipotesis nol (Ho) ditolak dan hipotesis alternatif ( $\mathrm{Ha})$ diterima atau ada hubungan yang signifikan antara hubungan infrastruktur dengan kepuasan pasien di Puskesmas Kecamatan Jagakarsa Tahun 2015.

Hasil analisis hubungan kualitas SDM dengan kepuasan pasien di Puskesmas Kecamatan Jagakarsa Tahun 2015, diketahui dari 79 responden umumnya menyatakan kualitas SDM di Puskesmas Kecamatan Jagakarsa Tahun 2015 tergolong baik dan pasien merasakan puas sebanyak 62 responden (87\%) sedangkan kualitas SDM buruk dan pasien merasakan puas sebanyak 17 responden (59\%) di Puskesmas Kecamatan Jagakarsa Tahun 2015. Hasil penelitian menunjukan bahwa pasien yang mengaku puas pada kualitas SDM kurang baik (buruk), responden menganggap keramahan dan kesabaran dari petugas Puskesmas yang kurang. Dari sisi tenaga medis, kesigapan dan keramahan perawat serta ketepatan waktu dokter saat kunjungan. Namun, responden tetap datang ke Puskesmas Kecamatan Jagakarsa karena mereka merasa nyaman dan sudah memiliki pengalaman sebelumnya baik dengan dokter maupun perawat Puskesmas yang sama.

Hasil uji diperoleh nilai OR (Odds Rasio $)=$ 4,86 artinya pasien yang mengaku puas pada penilaian kualitas personel memiliki proporsi lebih tinggi 4,8 kali dibandingkan dengan pasien yang puas dengan persepsi penilaian kualitas personel buruk. Hasil uji statistik chi square hubungan kualitas SDM dengan kepuasan pasien di Puskesmas Kecamatan Jagakarsa Tahun 2015 diperoleh nilai $\mathrm{p}=0,003$ artinya $p$. value $\leq$ alpha $(0,05)$, sehingga dapat disimpulkan hipotesis nol (Ho) ditolak dan hipotesis alternatif (Ha) diterima atau ada hubungan yang signifikan antara kualitas SDM dengan kepuasan pasien di Puskesmas Kecamatan Jagakarsa Tahun 2015. Hasil analisis hubungan tanggung jawab sosial dengan kepuasan pasien di Puskesmas Kecamatan Jagakarsa Tahun 2015, diketahui dari 79 responden umumnya menyatakan tanggung jawab sosial di Puskesmas Kecamatan Jagakarsa tergolong baik dan pasien merasakan puas sebanyak 67 responden (85\%) sedangkan tanggung jawab sosial buruk dan pasien merasakan puas sebanyak 12 responden (57\%) di Puskesmas Kecamatan Jagakarsa Tahun 2015.

Hasil uji diperoleh nilai OR (Odds Rasio) = 2,86 artinya pasien yang mengaku puas pada penilaian tanggung jawab sosial memiliki proporsi lebih baik 2,8 kali dibandingkan dengan pasien yang puas dengan persepsi penilaian tanggung jawab sosial buruk. Hasil uji statistik chi square hubungan tanggung jawab sosial dengan kepuasan pasien di Puskesmas Kecamatan Jagakarsa Tahun 2015 diperoleh nilai $\mathrm{p}=$ 0,152 artinya $p$. value $>$ alpha $(0,05)$, sehingga dapat 
disimpulkan hipotesis nol (Ho) diterima dan hipotesis alternatif (Ha) ditolak atau tidak ada hubungan antara tanggung jawab sosial dengan kepuasan pasien di Puskesmas Kecamatan Jagakarsa Tahun 2015. Hasil penelitian bivariat selengkapnya dapat dilihat pada table berikut:

Tabel 2. Analisis Bivariat

\begin{tabular}{|c|c|c|c|c|c|c|c|}
\hline \multirow{3}{*}{ Variabel } & \multicolumn{4}{|c|}{ Kepusan pasien } & \multirow{3}{*}{ Total } & \multirow{3}{*}{$\begin{array}{c}\text { P- } \\
\text { Value }\end{array}$} & \multirow{3}{*}{ OR } \\
\hline & \multicolumn{2}{|c|}{ Tidak puas } & \multicolumn{2}{|c|}{ Puas } & & & \\
\hline & $\mathbf{n}$ & $\%$ & $\mathbf{n}$ & $\%$ & & & \\
\hline \multicolumn{8}{|l|}{ Infrastruktur } \\
\hline Buruk & 12 & 43 & 16 & 57 & 28 & $0,00,2$ & 5,25 \\
\hline Baik & 9 & 13 & 63 & 88 & 27 & & \\
\hline \multicolumn{8}{|l|}{ Kualitas SDM } \\
\hline Buruk & 12 & 41 & 17 & 59 & 29 & 0,003 & 4,86 \\
\hline Baik & 9 & 13 & 62 & 87 & 71 & & \\
\hline \multicolumn{8}{|c|}{ Tanggung jawab sosial } \\
\hline Buruk & 13 & 36 & 14 & 64 & 22 & 0,072 & 2,86 \\
\hline Baik & 13 & 17 & 65 & 83 & 78 & & \\
\hline
\end{tabular}

\section{Pembahasan}

Pertama, responden menilai pelayanan administrasi merupakan indikator yang paling dominan dalam mempengaruhi kepuasan terhadap perawatan secara keseluruhan di Puskesmas Kecamatan Jagakarsa dibanding indikator lain. Kepuasan adalah keadaan emosional seseorang, perasaan senang atau kecewa yang timbul akibat membandingkan kinerja hasil terhadap ekspektasi. Apabila responden menilai pelayanan administrasi yang diberikan baik, maka kualitas pelayanan akan dipersepsikan baik dan memuaskan. Jika jasa yang diterima mampu melampaui harapan responden, maka kualitas pelayanan akan dipersepsikan ideal. Sebaliknya, jika kualitas pelayanan administrasi yang diterima lebih rendah dari yang diharapkan, maka akan dipersepsikan buruk dan tidak memuaskan. ${ }^{16}$

Kualitas pelayanan administrasi tergantung pada kemampuan penyediaan pelayanan administrasi Puskesmas Kecamatan Jagakarsa, baik secara sistem, teknologi maupun sumber daya manusia dalam memenuhi harapan responden secara konsisten dan Secara keseluruhan, pelayanan administrasi di Puskesmas Kecamatan Jagakarsa sudah cukup memuaskan. $^{17}$

Kedua, indikator biaya perawatan berpengaruh terhadap kepuasan responden secara keseluruhan di Puskesmas Kecamatan Jagakarsa. Kemudahan mendapatkan pelayanan juga menjadi faktor penting yang mempengaruhi kepuasan pelanggan. Pelanggan akan merasa puas jika mereka dapat dengan mudah mengakses layanan yang dibutuhkan. Kemampuan akses ini bisa diartikan terjangkau dari segi biaya. ${ }^{18}$ Dari hasil penelitian diketahui bahwa sebagian besar responden berpendapat tarif yang diberikan oleh Puskesmas Kecamatan Jagakarsa sesuai dengan perawatan medis yang mereka terima. Biaya perawatan merupakan faktor yang sensitif. Responden tentu berharap membayar biaya perawatan dengan harga yang seminimal mungkin namun mendapatkan pelayanan yang maksimal. Disinilah pentingnya Puskesmas Kecamatan Jagakarsa untuk menjaga hubungan baik dengan konsumen selama pelayanan maupun setelah mereka pulang. Perlu diingat bahwa biaya untuk menarik konsumen baru jauh lebih mahal daripada mempertahankan konsumen lama. Biaya menarik konsumen baru tidak sebanding dengan keuntungan yang dihasilkan oleh konsumen lama. Reichheld dan Sasser dalam Barnes (2003), mengindikasikan bahwa 5\% dari loyalitas konsumen dapat melipatgandakan profit perusahaan. Selain itu, konsumen lama juga lebih kurang sensitif terhadap perubahan atau kenaikan harga.

Indikator yang ketiga yaitu pelayanan medis juga berpengaruh terhadap kepuasan responden. merupakan inti pelayanan yang diberikan Puskesmas kepada konsumen. Pasien datang ke Puskesmas untuk mendapatkan pelayanan kesehatan dan mengharapkan kesembuhan. mencakup unsur pelayanan medis, penunjang medis, dan pelayanan oleh non-profesi kesehatan. Dalam proses layanan klinis, pasien akan melewati serangkaian tahapan seperti anamnesis, pemeriksan fisik, pemeriksaan laboratorium dan/atau radiologi, serta mengambil obat di bagian farmasi. Pelayanan medis yang baik harus didukung oleh praktisi medis yang rasional, mengutamakan pencegahan, mengobati penyakit sebagai keseluruhan, kerjasama antara dokter dan pasien serta mengaplikasikan keilmuan dan tatalaksana terbaru yang dibutuhkan pasien. 


\section{Hubungan Infrastruktur dengan Kepuasan pasien}

Hasil penelitian hubungan infrastruktur dengan kepuasan pasien di Puskesmas Kecamatan Jagakarsa diperoleh nilai $\mathrm{p}=0,002$ artinya $p$. value $\leq$ alpha $(0,05)$, sehingga disimpulkan ada hubungan yang signifikan antara hubungan infrastruktur dengan kepuasan pasien di Puskesmas Kecamatan Jagakarsa.

Hasil penelitian ini menyatakan bahwa ketersediaan infrastruktur merupakan kemampuan suatu perusahaan dalam menunjukkan eksistensinya kepada pihak eksternal. Penampilan kantor dan karyawan, kemampuan sarana dan prasarana fisik perusahaan (termasuk fasilitas komunikasi), serta lingkungan sekitarnya adalah bukti nyata dari pelayanan yang diberikan oleh pembeli jasa. Penampilan pelayanan tidak hanya sebatas pada penampilan fisik bangunan yang megah tetapi juga penampilan petugas dan ketersediaan sarana dan prasarana penunjang. ${ }^{19}$

Hasil penelitian ini juga sejalan dengan penelitian tentang dimensi dari pelayanan kualitas total pada pelayanan kesehatan. Dimensi yang paling prioritas dan memiliki hubungan yang signifikan dengan kepuasan pasien adalah salah satunya ketersediaan infrastruktur yaitu kualitas dari fasilitas fisik seperti peralatan, pengaturan bangsal, tampilan gedung Puskesmas, ruang tunggu, ruang pemeriksaan klinis dan diagnostik. $^{20}$

Meskipun sebagian besar responden menilai fasilitas infrastruktur kesehatan di Puskesmas Kecamatan Jagakarsa sudah baik namun masih ada beberapa hal yang perlu diperbaiki atau ditingkatkan untuk mendukung pelayanan yang maksimal. Beberapa responden mengeluhkan pendingin ruangan (AC) yang kurang sejuk, tidak adanya fasilitas kantin, ruang ibadah dan ruang senam hamil, lahan parkir yang terbatas, jam besuk yang kurang disiplin, letak ruang bayi yang jauh dari kamar IGD, jumlah kamar dan tempat tidur yang terbatas serta kebersihan dan kenyamanan kamar dan kamar mandi yang perlu ditingkatkan. Beberapa saran dari responden yaitu meletakkan lebih banyak tempat sampah di ruang tunggu serta membedakan tempat sampah kering dan basah.

Peneliti sendiri mencoba memberikan beberapa saran yang berkaitan dengan sarana dan prasarana, yaitu setiap tempat pelayanan sebaiknya dilengkapi dengan sabun cuci tangan di kamar mandi diletakkan menempel ke tembok, menempelkan prosedur mencuci tangan yang benar (kriteria WHO) di tempat yang sesuai.

Kesadaran untuk menjaga kualitas infrastruktur perlu diupayakan guna memberikan kepuasan terhadap pasien serta karyawan. Perusahaan jasa khususnya kesehatan dituntut untuk meningkatkan kualitas infrastruktur yang berorientasi pada tingkat kepuasan pasien serta mengubah pandangan negatif masyarakat terhadap pelayanan kesehatan khususnya Puskesmas Kecamatan Jagakarsa.

\section{Hubungan Kualitas SDM dengan Kepuasan pasien}

Hubungan kualitas SDM dengan kepuasan pasien di Puskesmas Kecamatan Jagakarsa diperoleh nilai $\mathrm{p}=0,003$ artinya $p$. value $\leq$ alpha $(0,05)$, sehingga disimpulkan ada hubungan yang signifikan antara kualitas SDM dengan kepuasan pasien di Puskesmas Kecamatan Jagakarsa.

Hal ini menunjukkan bahwa sebagian besar responden menilai kualitas SDM di Puskesmas Kecamatan Jagakarsa dalam kategori baik selama dirawat di Puskesmas Kecamatan Jagakarsa. Sebagian kecil responden masih mengharapkan kualitas SDM lebih ditingkatkan sehingga dapat melayani pasien dengan lebih optimal. Dari hasil penelitian, responden mengeluhkan petugas keamanan yang kurang ramah dan sopan terhadap pasien dan keluarganya, petugas administrasi yang kurang ramah dan sabar. Dari sisi tenaga medis (dokter dan perawat), responden mengeluhkan beberapa hal seperti keramahan, kesigapan, kesabaran dalam menerima pasien (perawat), komunikasi yang belum optimal dengan pasien (perawat tidak memperkenalkan diri kepada pasien), kesediaan waktu dokter untuk menjelaskan mengenai diagnosis dan hasil pengobatan, ketepatan waktu kunjungan di , dan lain-lain. ${ }^{20}$

Hasil penelitian ini sejalan dengan penelitian tentang dimensi dari pelayanan kualitas total pada pelayanan kesehatan. Dimensi yang paling prioritas dan memiliki hubungan yang signifikan dengan kepuasan pasien adalah salah satunya kualitas SDM yaitu pelayanan oleh dokter, perawat, kualitas paramedis dan staf pendukung dan kualitas komunikasi. Pelayanan yang diberikan oleh dokter, perawat, dan staf pendukung merupakan faktor penting dalam menciptakan kepuasan pasien terhadap pelayanan kesehatan. Keterampilan, pengalaman, kehangatan, respon, dan perhatian mereka dinilai dalam dimensi ini. ${ }^{20}$

Diantara dokter, perawat dan staf pendukung, perawat merupakan tenaga kesehatan yang paling sering berinteraksi dengan pasien. Oleh karena itu, perawat dituntut untuk memiliki keahlian dibidangnya dan lebih memprioritaskan kebutuhan para pasien. Menurut teori Dever (1984), salah satu faktor yang mempengaruhi 
permintaan pelayanan kesehatan adalah interaksi antara konsumen (pasien) dengan petugas kesehatan, dimana hubungan tersebut dilandasi adanya saling menghargai hak dan kewajiban masing-masing pihak.

Menurut peneliti, tanggapan yang positif atau negatif dari masyarakat di suatu pelayanan kesehatan ditentukan oleh keberhasilan ataupun kegagalan interaksi antara dokter, perawat dan pasien. Pelayanan yang lebih responsif terhadap keluhan dan harapan pasien akan menghasilkan kerjasama yang baik antara pasien dengan dokter. Kualitas SDM yang baik adalah jika perawat atau dokter mampu memberikan pelayanan kesehatan dengan cepat, tepat dan ramah.

\section{Hubungan Tanggung Jawab dengan Kepuas an pasien}

Hasil analisis hubungan tanggung jawab sosial dengan kepuasan pasien di Puskesmas Kecamatan Jagakarsa Tahun 2015, diketahui dari 79 responden umumnya menyatakan tanggung jawab sosial di Puskesmas Kecamatan Jagakarsa tergolong baik dan pasien merasakan puas sebanyak $85 \%$ responden. Pasien yang mengaku puas pada penilaian tanggung jawab sosial memiliki proporsi lebih baik 2,8 kali dibandingkan dengan pasien yang puas dengan persepsi penilaian tanggung jawab sosial buruk. Hasil uji statistik chi square hubungan tanggung jawab sosial dengan kepuasan pasien di Puskesmas Kecamatan Jagakarsa Tahun 2015 diperoleh nilai $\mathrm{p}=0,152$ artinya $p$. value $>$ alpha $(0,05)$, sehingga dapat disimpulkan tidak ada hubungan antara tanggung jawab sosial dengan kepuasan pasien di Puskesmas Kecamatan Jagakarsa Tahun 2015.

Hubungan pelayanan administrasi dengan kepuasan pasien di Puskesmas Kecamatan Jagakarsa diperoleh nilai $\mathrm{p}=0,021$ artinya $p$. value $\leq$ alpha $(0,05)$, sehingga disimpulkan ada hubungan yang signifikan antara pelayanan administrasi dengan kepuasan pasien di Puskesmas Kecamatan Jagakarsa.

Kegiatan sosial merupakan suatu bentuk solidaritas puskesmas bagi masyarakat, sekaligus bermanfaat dalam membentuk citra puskesmas melalui publikasi yang tepat yang akan membantu puskesmas membangun kerjasama dengan masyarakat sekitar. Puskesmas dapat berperan melalui kegiatan bakti sosial, penyuluhan rutin yang dapat diadakan setiap minggu atau bulan, misalnya mengenai penggunaan $\mathrm{KB}$ untuk ibu-ibu yang berusia di atas 35 tahun, pemeriksaan IVA (Inspeksi Visual dengan Asam Asetat) untuk mendeteksi kanker serviks, pemberian imunisasi dasar gratis pada pekan imunisasi nasional, pemberian makanan tambahan pada balita secara gratis pada hari anak nasional, dan lain-lain.

Puskesmas bertanggung jawab dalam melaksanakan kewajibannya yang bertujuan untuk memberi pelayanan kesehatan kepada pasien. Dalam pelayanannya, puskesmas harus memiliki standar seperti standar prosedur operasional, standar pelayanan medis dan standar asuhan keperawatan. Puskesmas perlu menerapkan prinsip-prinsip etika (adil) dalam memberikan pelayanan kesehatan di antara strata yang berbeda dalam masyarakat. Puskesmas perlu memberikan pelayanan yang baik dengan biaya yang wajar tanpa harus mengurangi kualitas.

\section{Kesimpulan}

Berdasarkan hasil penelitian tentang pengaruh peran Total Quality Service (TQS) terhadap kepuasan pasien di Puskesmas Kecamatan Jagakarsa, maka dapat disimpulkan bahwa : Karakteristik pasien yang dirawat di Puskesmas Kecamatan Jagakarsa adalah sebagian besar berusia antara 26 tahun hingga 35 tahun yaitu sebanyak 56\%. Pendidikan responden lebih banyak D3 yaitu 45\%. Pekerjaan responden sebagian besar sebagai PNS yaitu 45\%. Infrastruktur, kualitas SDM dan tanggung jawab sosial di Puskesmas Kecamatan Jagakarsa termasuk dalam kategori baik dan sesuai dengan rata-rata nilai frekuensi diatas $70 \%$. Infrastruktur dan kualitas SDM memiliki hubungan yang signifikan dengan kepuasan pasien dalam pelayanan BPJS di Puskesmas Kecamatan Jagakarsa. Sedangkan tanggung jawab sosial tidak memiliki hubungan dengan kepuasan pasien dalam pelayanan BPJS di Puskesmas Kecamatan Jagakarsa.

\section{Saran}

Berdasarkan hasil penelitian di Puskesmas Kecamatan Jagakarsa, maka penulis mencoba memberikan saran sebagai pertimbangan dan masukan bagi peneliti selanjutnya, yaitu: Bagi Puskesmas Kecamatan Jagakarsa. (a) Kualitas SDM. Diharapkan petugas keamanan menunjukan sikap ramah, sopan dan sabar terhadap pasien dan keluarganya. Diperlukan perbaikan kulaitas SDM dari segi keramahan, kesigapan, kesabaran dalam menerima pasien (perawat), komunikasi yang belum optimal dengan pasien (perawat tidak memperkenalkan diri kepada pasien), kesediaan waktu dokter untuk menjelaskan mengenai diagnosis dan hasil pengobatan dan ketepatan waktu kunjungan. Pemeriksaan dan prosedur medis serta hasil pengobatan perlu dijelaskan oleh dokter yang bersangkutan secara detail. (b) Infrastruktur Perlunya perbaikan Fasilitas fisik 
dan infrastruktur puskesmas dan perlu ditinjau ulang kelengkapan yang Obat yang tersedia di apotek agar memudahkan pasien membeli resep obat, sehingga keluarga pasien tidak perlu keluar area puskesmas.

Bagi peneliti selanjutnya, diharapkan dapat menelaah lebih dalam serta mengembangkan penelitian lebih lanjut mengenai faktor-faktor lain yang belum diteliti pada penelitian ini, yang dapat mempengaruhi kepuasan pasien di Puskesmas. Untuk memperdalam analisis, pendekatan penelitian selanjutnya dapat bersifat kualitatif.

\section{Daftar Pustaka}

1. Depkes R.I. Profil Kesehatan Indonesia Jakarta: Depkes RI; 2008.

2. Muninjaya. Manajemen Mutu Pelayanan Kesehatan, Edisi 2 Jakarta: EGC; 2010.

3. Ilyas, S.. Kedaruratan Dalam Ilmu Penyakit Mata Jakarta: Balai Penerbit FKUI; 2009.

4. Muninjaya, Manajemen Mutu Pelayanan Kesehatan, Edisi 2 Jakarta: EGC; 2011.

5. Sari. Manajemen : Pemasaran Usaha Kesehatan. Jogjakarta : Penerbit Mitra; 2009.

6. Depkes RI. Capaian Pembangunan Kesehatan. Jakarta: Depkes RI; 2011.

7. Kanuk L \& Schiffman L. Perilaku Konsumen. Jakarta: Penerbit PT. Indeks; 2011

8. Depkes RI. Capaian Pembangunan Kesehatan Tahun 2010. Jakarta: Depkes RI; 2010.
9. Depkes. R.I. Profil Kesehatan Indonesia. Jakarta: Depkes RI; 2010.

10. Sulistyaningsih. Metodologi Penelitian Kuantitatif dan Kualitatif. Yogyakarta : Graha Ilmu; 2011.

11. Notoadmodjo. S. Metodologi Penelitian Kesehatan. Jakarta: Penerbit Rineka Cipta; 2010.

12. Notoadmodjo. S. Metodologi Penelitian Kesehatan. Jakarta: Penerbit Rineka Cipta; 2011.

13. Arikunto. S. Prosedur Penelitian: Suatu Pendekatan Praktek, Edisi Revisi V Jakarta: Penerbit Rineka Cipta; 2002.

14. Arikunto. S. Prosedur Penelitian: Suatu Pendekatan Praktek, Edisi Revisi V Jakarta: Penerbit Rineka Cipta; 2002.

15. Sugiyono. Metodologi Penelitan Bisnis, Bandung: Penerbit CV Alfabeta; 2005.

16. Purwanto. Kepuasan Pasien terhadap Pelayanan Rumah Sakit. Tahun 2007. Available online at http://klinis. wordpress.com diakses 15 Mei 2015.

17. Kotler. P dan KellerK. Manajemen Pemasaran, Edisi 13 Jilid 1. Jakarta: Penerbit Erlangga; 2009.

18. Jacobalis. Sepuluh Prinsip Kepuasan Pelanggan, Jakarta: PT Elex Media Komputindo; 2003.

19. Lupioadi. SERVQUAL dan Perilaku Konsumen, Jakarta, Penerbit PT. Ghalia Indonesia; 2008.

20. Duggirala. M. Rajendran. C. \& Anantharaman. R. N. Patient-perceived dimensions of Total Quality Service in healthcare. Benchmarking: An International Journal, 155, 560-583; 2008 